\title{
13. Linking climate change mitigation and poverty reduction: continued reform of the clean development mechanism in the post-Kyoto era to promote sustainable energy development on the African Continent
}

\section{Daniel Behn}

\subsection{INTRODUCTION}

There is concern from a human development perspective that demands to reduce global greenhouse gasHG) emissions will unjustly deprive developing countries of the same opportunities for industrialization already afforded to the developed world. Humanitarians argue that such a limitation could inequitably deny the developing world from achieving the economic development needed to free its populations from extreme poverty. Yet choices to eradicate extreme poverty or solve the global climate change problem need not be mutually exclusive.

Central to both pursuits is the access to, and use of, energy in all of its forms. The links between human development and access to energy are welldocumented. ${ }^{1}$ Equally documented are the links between fossil fuel consumption and the emission of carbon dioxide $\left(\mathrm{CO}_{2}\right)$ into the atmosphere. ${ }^{2}$ One way to pursue both objectives is through global policies that encourage the development of sustainable energy in the developing world. This is particularly important on the African continent where access to energy is limited and extreme poverty is widespread. ${ }^{3}$ In compelling the human race to embrace such an approach, an opportunity has emerged in the twenty-first century to both eradicate extreme poverty and stabilize the planet that we collectively inhabit.

There are internationally agreed upon targets for extreme poverty reductions and GHG emission reductions: the Millennium Development Goals 
$(\mathrm{MDGs})^{4}$ and the Kyoto Protocol ${ }^{5}$ respectively. Implicit in the achievement of the MDGs targets is a drastic reduction in energy poverty in the poorest parts of the world. ${ }^{6}$ On the other hand, the achievement of the targets set by the Kyoto Protocol requires a global reduction in GHG emissions - the unwanted by-product of fossil fuel based energy production. While the industrialized world focuses on reducing energy consumption, the developing world is focusing on increasing energy production. Despite these policy agendas aimed at both curbing extreme poverty and GHG emissions, the industrialized countries of the world continue to burn fossil fuels at unsustainable rates while 1.6 billion people still have no access to electricity - including 85 percent of the rural population on the African continent. ${ }^{7}$

To exacerbate such inequity, the effects of global climate change - primarily caused by the industrialized world - will be borne disproportionately by the poorest populations in the world. While the industrialized world should arguably bear most of the cost for mitigating global GHG emissions, acknowledgement that they also bear the duty to financially and technically assist the poorest countries in their efforts to adapt to the future impacts of climate change has been slow to come. However, recent progress in this regard has been substantial. ${ }^{8}$ The announcement of the development of a robust 100 billion dollar a year Green Climate Fund indicates that the post-Kyoto era appears to be aimed at remedying some of these key energy poverty issues. ${ }^{9}$

Overall though, the seemingly obvious links between climate change, energy use, and extreme poverty are not explicitly integrated into either the MDGs or the Kyoto Protocol. Implicitly however, the past ten years has seen the development of a potentially transformative approach for addressing both energy poverty and climate change. Dubbed the 'Kyoto surprise,' the Clean Development Mechanism (CDM) appeared late in the negotiations of the Kyoto Protocol as a market-based innovation linking sustainable development with the task of reducing GHG emissions through an endorsement of carbon emission trading between developed and developing countries (Yamin, 1998, p. 115).

Coupled with the Joint Implementation mechanism (JI), the Kyoto Protocol embraces these so-called flexible mechanisms as a way for industrialized countries to meet their GHG emission reduction targets by investing in GHG emission reducing projects in developing and transitional economies (Wright, 2007). However, the development process of the CDM has been guided by a 'learn-by-doing' approach and as such has experienced a number of significant initial growing pains. ${ }^{10}$ And while the CDM has arguably only provided marginal sustainable energy development benefits during the first compliance period of the Kyoto Protocol (2008 through 2012), the post-Kyoto framework should continue to embrace the CDM; albeit with a continued focus on reforming the CDM towards the provision of specific sustainable development 
benefits to the poorest countries of the world - particularly the least developed countries (LDCs) on the African continent (Subbarao and Lloyd, 2011).

This chapter aims to identify the limiting factors of the current CDM and to advocate for a mechanism in the post-Kyoto era that will provide LDCs with improved opportunities for pursuing sustainable energy development strategies. Section 13.2 will outline the structures and function of the CDM as implemented during the first compliance period. Sections 13.3, 13.4, and 13.5 will identify and analyze the operational and institutional deficiencies that have emerged in the implementation of the CDM. Section 13.6 will propose a reform agenda for the CDM in the post-Kyoto era; a modified framework and set of rules better designed to facilitate sustainable energy development in African and other slow developing countries.

\subsection{GOALS AND STRUCTURE OF THE CDM}

There is a broadening scientific consensus that the anthropomorphic activity over the preceding two centuries, primarily from the uninhibited use of inexpensive fossil fuels, has led to greatly increased GHG concentrations in the earth's atmosphere. ${ }^{11}$ Projections hold that these increased concentrations of industrial gases in the atmosphere will warm the earth's surface temperature, and in turn, lead to a rise in sea levels, changes in crop patterns, and increasingly extreme weather conditions. ${ }^{12}$ The most significant global response to climate change is manifest in the Kyoto Protocol: a binding commitment by the industrialized nations of the world (except the United States (US)) to reduce GHG emissions to approximately 5 per cent below 1990 levels (Gerrard, 2007, p. 38). To achieve such targets, the Kyoto Protocol embraces a market-based cap-and-trade approach to GHG emission reductions.

Under such a cap-and-trade system, industrialized nations with Kyoto Protocol commitments (Annex B countries) can use a variety of means in which to meet their target reductions in the first compliance period (Gerrard, 2007, pp. 42-50). The Kyoto Protocol includes a number of flexible mechanisms aimed at reducing the cost of compliance for Annex I countries (industrialized countries that are party to the United Nations Framework Convention on Climate Change (UNFCCC)). ${ }^{13}$ One such mechanism, the CDM, allows developed countries to invest in GHG emission reduction projects in developing countries. The investing country can then use the resulting earned emission credits to meet its own GHG emission reduction commitments. ${ }^{14}$ The CDM's innovation, however, comes not in its endorsement of a carbon trading system, but rather in its requirement to bring sustainable development benefits to developing countries. The investors in such projects, either a government agency or private corporation, earn Certified Emission Reductions (CER): a 
form of carbon credit that an investor can either sell or use to meet a portion of its own emission reduction obligations under the Kyoto Protocol. ${ }^{15}$

The objectives of the CDM under Article 12 of the Kyoto Protocol are twofold. First, the CDM seeks to provide a market-based mechanism through which governments and private sector entities in developed countries can invest in projects that will enable them to reduce global GHG emissions at a lower cost per ton of $\mathrm{CO}_{2}$ emitted. ${ }^{16}$ Second, the CDM is a device to assist developing countries in achieving their sustainable development objectives (Wara, 2008, p. 1765).

The CDM emerged late in the Kyoto Protocol negotiations as a compromise designed to promote cooperation between developing and developed countries. The Brazilian delegation had proposed the establishment of a fund under the Kyoto Protocol that would compel developed countries to finance adaptation projects in developing countries (Yamin, 1998, p. 115). While the proposed fund did not succeed, the resulting CDM incorporated design elements to achieve a similar objective. ${ }^{17}$ Promoted under the Kyoto Protocol as a means to meeting the overall objectives of the UNFCCC, the CDM provides the potential for win-win opportunities: developed countries can stabilize their GHG emissions, while at the same time encouraging sustainable development in developing countries (Wara, 2008, pp. 1765-1766).

Developed countries benefit from the CDM in two ways. First, they can use the mechanism as an alternative mode of compliance when they are unable to meet commitment targets by regulating their domestic industries. Second, they are able to reduce the compliance costs of meeting their domestic obligations because GHG emission reductions are often achievable at a much lower marginal cost in developing countries (Wara, 2008, p. 1765-1766). There are two key limitations, however. One is that CDM projects must adhere to a supplementarity principle: all CDM projects must be supplemental to domestic efforts to meet Kyoto Protocol commitments. ${ }^{18} \mathrm{CDM}$ projects are likewise limited in that they cannot receive financing through a diversion of Official Development Assistance (ODA) funds already targeted for other programs. Essentially envisioned as a market-based program, primary funding of CDM projects should originate in the private sector.

For the developing world, the CDM was envisioned as a tool for promoting investment and technology transfer opportunities, while at the same time, enabling Non-Annex I countries (non-industrialized countries that are party to the UNFCCC) to achieve some of their sustainable development objectives. ${ }^{19}$ By encouraging sustainable development, the CDM could theoretically provide Non-Annex I parties with financial incentives for low carbon intensity development in the hope of nudging them onto more climate friendly trajectory. In hosting CDM projects, developing countries could potentially attract much needed foreign direct investment (FDI) in energy and infrastructure 
development, reap associated local air quality and health benefits, gain access to low-cost or no-cost technology transfers, promote institutional capacity building, improve land use, support rural development, and help promote sustainable energy development. ${ }^{20}$

Operationally however, the flexible mechanisms permitted under the Kyoto Protocol were little more than an empty shell after the landmark UNFCCC Conference of the Parties (COP) in Kyoto, Japan in 1997 (Lecocq and Ambrosi, 2007, p. 136). It was not until 2001 at the UNFCCC COP in Bonn, Germany that negotiation of the actual framework for international emissions trading under the CDM and the JI took place. The following year, at the COP in Marrakesh, Morocco, the parties agreed to a rulebook for the operational modes and modalities that would regulate the project cycle under the CDM and JI. ${ }^{21}$ While the rulebook provided much needed guidance in the implementation of the flexible mechanisms under the Kyoto Protocol, its specific requirements have arguably hindered the effectiveness of the CDM in achieving some of its goals (Timilsina, 2009). ${ }^{22}$

As per the Marrakesh Accords, the CDM is a project-based system that accomplishes its objectives through an individually approved and validated project cycle. Each project's proposal starts with a Project Design Document (PDD), which includes inter alia, a description of the project, the baseline and monitoring methodologies, ${ }^{23}$ and the environmental impacts of the project (Lecocq and Ambrosi, 2007, pp. 137-138). The PDD must explain in detail how future emission reductions from the project will be voluntary, ${ }^{24}$ real, ${ }^{25}$ additional, ${ }^{26}$ and not induce leakage. ${ }^{27}$ All four of these concepts require definition of a hypothetical baseline of emissions. This baseline represents the timeline of emissions that would have occurred absent the subsidy provided by the CDM project. ${ }^{28}$

Once finalized, both the host government (the Non-Annex I country) and the sponsoring government (the Annex I country) must approve the PDD. In order to participate in CDM projects, each developing country must establish a Designated National Authority (DNA) that is responsible for approving projects and verifying that the projects contribute to sustainable development. ${ }^{29}$ If approved, the DNA of both the developing country and the developed country must issue a Letter of Approval (LoA) stating that participation in the CDM is voluntary and will contribute to the host country's sustainable development objectives. The PDD and the LoA must then be validated by an independent third party (typically an auditing company), the Designated Operational Entity (DOE) (Lecocq and Ambrosi, 2007, pp. 137-138). By validating the project, the DOE determines that all parties approve the project, and that it correctly applies the selected baseline and monitoring methodologies. ${ }^{30}$ The PDD and LoAs then go to the CDM Executive Board (CDM EB), who registers the project and monitors its progress (Lecocq and Ambrosi, 2007, pp. 
137-138). After becoming operational, the CDM EB is responsible for issuing the earned CER credits, and depositing them into the account of the project participant. CER credits are equal to the GHG emission reduction of one ton of $\mathrm{CO}_{2}$ equivalent, and are a fungible commodity tradable interchangeably with other Kyoto Protocol allowances (CER credits, Emission Reduction Units (ERUs), and Assigned Allocation Units (AAUs)).

\subsection{SUSTAINABLE DEVELOPMENT AND THE CDM}

A measurement of the exact sustainable development indicators as they relate to CDM projects remains a challenge. However, the initial operation of the $\mathrm{CDM}$ as implemented under the Kyoto Protocol, the Bonn framework, and the Marrakesh rules has not resulted in the significant development of sustainable energy projects on the African continent or other slow developing countries (Fenhann and Staun, 2010; de Lopez, 2009; Timilsina, 2010). Though the $\mathrm{CDM}$ has proven successful as a means for reducing global GHG emissions at a lower cost than would be possible for developed countries domestically, the CDM has not effectively promoted energy development aimed at reducing extreme poverty. ${ }^{31}$ Fortunately, the CDM EB is acutely aware of this criticism; and is currently working on remedying many inadequacies as they relate to the limited popularity of sustainable energy projects in LDCs. ${ }^{32}$ One key initiative currently being developed is to provide special loans and assistance to LDCs that have registered fewer than ten projects. ${ }^{33}$

As of 15 May 2011, the CDM EB has registered 3100 projects with more than 6200 projects in the pipeline. ${ }^{34}$ Of the projects currently registered globally, the majority of CDM projects are concentrated in Latin America and Asia with only 61 registered projects on the African continent. ${ }^{35}$ Further, of the projected CER credits that will be issued worldwide from CDM projects through the end of the first commitment period, only 25 per cent will come from renewable energy projects. ${ }^{36}$

On the other hand, 25 per cent of expected CER credits after the first commitment period will come from projects aimed at the capture and destruction of industrial gases that are the unwanted by-product of nylon-22 and Teflon ${ }^{\circledR}$ production. ${ }^{37}$ These so-called hydrofluorocarbon-23 (HFC-23) and nitrous oxide $\left(\mathrm{N}_{2} \mathrm{O}\right)$ abatement projects have produced a large number of CER credits in India and China. ${ }^{38}$ Unfortunately, these projects have severely undermined the credibility of the CDM process by creating false credits at inflated costs with no sustainable development benefits (Wara, 2008, pp. 1768-1770). It can be noted, however, that the inadequacies related to CDM abatement projects have largely been resolved and will not feature prominently in the future development of the CDM. ${ }^{39}$ As recently as 2008 , it was 
predicted that abatement projects would account for over 50 per cent of all the expected CER credits to be issued during the first commitment period (Wara, 2008, pp. 1768-1770). The fact that this number is currently down to 25 per cent indicates great progress in the promotion on non-abatement type projects throughout the world.

It was initially predicted that the operation of the CDM would result in a significant percentage of projects that have substantial sustainable development benefits: renewable energy, fuel switching, waste heat capture, and demand-side energy efficiency. However, CER credits issued to date have come from a less than optimal percentage of sustainable energy projects. ${ }^{40}$ However, this too is changing. Recent increases in demand-side efficiency projects, wind energy projects, and biomass energy production indicate concerted efforts by the CDM to remedy many of the initial barriers to entry that these types of projects faced ${ }^{41}$ However, it remains the case that CDM projects remain disproportionately absent from the African continent (Timilsina, 2010; Byigero, 2010). The reason for the CDM's limited influence in Africa is likely the result of both CDM operational deficiencies and institutional governance deficiencies among LDCs in Africa. In order to make the CDM work as a tool for promoting sustainable energy development with poverty reduction benefits on the African continent, both deficiencies need correction.

\subsection{OPERATIONAL BARRIERS}

Turning first to the operational deficiencies of the CDM itself, both procedural substantive barriers currently limit the effectiveness in bringing the CDM to the poorest regions of the world. These operational deficiencies are broadly classifiable into two categories: (1) inadequacies of the market-based approach and (2) inadequacies of specific substantive and procedural requirements. The first category includes the low-hanging fruit problem, the inadequate definition of sustainable development under the CDM, and the problems associated with using market mechanisms in environmental management. The second category includes problems relating to the additionality and baseline requirements, limitations on land use, forestry, and carbon sink projects, the registration of small-scale projects, the cumbersome and costly requirements of CDM project registration, and the uncertainty of the post-Kyoto framework for CDM-type projects.

While the market-based approach to addressing global climate change appears to have permanently seeped into the consciousness of the world's policy makers, it likewise has begun to appear that the same market-based approach has the potential to broaden development inequities between the 
global North and the global South (Nygard, 2009, p. 36). Instead of promoting projects that result in the greatest benefit to the greatest number of people, the CDM has rewarded green entrepreneurs who have manipulated the CDM in order to reap massive windfall profits from industrial gas abatement projects that have provided few, if any, sustainable development benefits. ${ }^{42}$ CDM projects with the greatest sustainable benefits are often costly, and the use - or misuse - of the CDM to procure CER credits at the lowest possible cost (the low-hanging fruit issue) has prevented the promotion of costlier or riskier sustainable projects in Africa. ${ }^{43}$ The low-hanging fruit issue states that developed country entities or foreign investors will first sponsor projects that are the most profitable, thus leaving the developing countries with only more expensive measures when they have to meet their own emission reduction commitments in the future ${ }^{44}$ However, it appears that CDM projects have now picked almost all the lowest-hanging fruit and there is a decided increase in projects with more limited profit margins. ${ }^{45}$

Another operational barrier to the promotion of CDM projects is the vagueness of the sustainable development requirement. Currently, any project that is found to reduce GHG emissions meets the sustainable development requirement. While the definition of sustainable development is malleable, it certainly requires more than climate change mitigation practices. ${ }^{46}$ By requiring a stricter definition of the sustainable development requirement, the CDM could mitigate some of the market-based issues addressed above.

Under the current market-based regime, CDM projects with substantial sustainable development benefits will appear prohibitively costly when forced to compete with projects that provide windfall profits at low or no-cost to the investor (such as industrial gas abatement projects) (Wara, 2008, p. 1765). Using a cost-minimizing marketable rights approach to sustainable energy development - when no factor other than $\mathrm{CO}_{2}$ emission reductions are taken into account - leads to distortion of the projects selected (such as low-hanging fruit projects), which may be far from the best projects to undertake in terms of sustainable development more broadly conceived.

The second category of deficiencies is describable as follows: in order to assure that CDM projects actually result in emission reduction benefits, the CDM implementing rules contain both substantive and procedural requirements that have interfered with creating more CDM projects. One such issue is the additionality requirement, which - as currently defined under the CDM - limits the possibility of projects on the African continent. Reductions in emissions must be in addition to any that would occur in the absence of the CDM project (the business-as-usual scenario) (Nelson, 2004, p. 636). Using this baseline approach rewards investors for cleaning up older fossil fuel based energy systems, but almost completely excludes projects that avoid future emissions through new renewable energy projects. Furthermore, this approach 
has limited the types of land use projects permitted under the CDM; only projects for reforestation and afforestation ${ }^{47}$ are authorized under the current modalities (Ellis and Kamel, 2007, p. 36). ${ }^{48}$

For Africa, the inclusion of projects that avoid deforestation could have a significant impact in both preserving forests and promoting projects that reduce the use of unsustainable biomass fuelwood through fuel switching projects (Laurance, 2007, pp. 20-24). Hence, an additionality requirement that is determined in terms of GHG emissions avoided instead of GHG emissions reduced could be possible. Under such an avoidance approach, investors would be rewarded for promoting projects that entirely bypass fossil fuel based energy development (so-called leap-frogging) (Laurance, 2007, pp. 20-24). However, such an avoidance approach represents a fundamental reality - if we give developed countries credit for assisting avoiding future emissions in developing countries and give them permission to continue to emit based on those credits, we have not reduced emissions at all. Therefore, a better solution may be to include a separate mechanism in the post-Kyoto agreement that rewards investors and states who avoid increasing emissions through poor land use choices, deforestation, and fossil fuel based energy development. Such a mechanism would encompass both the North and the South, but place substantial responsibility on the North to finance the incentives used to encourage nations in the South to make better land use decisions, avoid deforestation, and leap-frog over fossil fuel technologies.

The required costs and cumbersome processes of CDM registration further hinder CDM projects. The current CDM process encourages large-scale projects that can quickly reap CER credits at the lowest possible cost. Smallscale renewable energy projects or small-scale carbon sink projects do not fare well under the current CDM process (Fenhann and Staun, 2010). While there have been attempts to increase awareness of CDM opportunities in Africa through such initiatives as the Nairobi framework ${ }^{49}$ and the Africa Carbon Forum, ${ }^{50}$ the CDM process remains a challenge for countries on the African continent (Timilsina, 2010). For small-scale projects, the cost and time required to register a CDM project is often prohibitive (Sum Low, 2006, pp. 76-80).

The CDM process requires vast documentation, technical and scientific expertise, costs ranging from 30 to 250 thousand dollars, and times ranging from nine months to a year. ${ }^{51}$ There have been some recent attempts to remedy this problem by allowing the bundling of small-scale projects and allowing for programmatic CDM projects (called Program of Activity (PoA) projects) ${ }^{52}$ Under the bundling approach, registration of multiple small-scale projects - such as decentralized renewable energy projects in rural areas - are combinable, thus making the CDM registration process more feasible. ${ }^{53}$ Likewise, PoA projects allow developing countries to earn CER credits for 
programs (as opposed to individual projects) for reducing GHG emissions. ${ }^{54}$ These programmatic and bundling ideas have the potential to improve the administration of the CDM dramatically (Subbarao and Lloyd, 2011).

Finally, while the current operational guidelines of the CDM do permit the issuance of CER credits beyond the Kyoto Protocol's first compliance period, such credits could become valueless without future commitment periods that embrace a CDM-type program (Ellis and Kamel, 2007, pp. 40-41). While the 2007 Bali COP decided on a road map for post-Kyoto negotiations, ${ }^{55}$ the 2009 Copenhagen $\mathrm{COP}^{56}$ and the 2010 Cancun $\mathrm{COP}^{57}$ have failed to produce binding commitments for a second commitment period. As such, many projects that have long life spans - carbon sink projects and large-scale renewable energy projects - will not earn CER credits until after the first commitment period has concluded (Ellis and Kamel, 2007, pp. 40-41). However, the inclusion of a CDM-type program is likely in any future agreement, and therefore difficulties associated with post-Kyoto credits should disappear as soon as a long-term global agreement is adopted. ${ }^{58}$

Despite the fact that a binding second commitment period has not emerged, the continued reform, modification, and improvement of the major problems identified in the current CDM program is ongoing and promises to result in a more equitable distribution of projects, especially on the African continent. Therefore, while the current CDM has not been effective as a means for promoting sustainable energy development and poverty reduction on the African continent, the CDM concept remains visionary, and if properly reformed, promises to be a powerful development tool in the post-Kyoto era.

\subsection{INSTITUTIONAL BARRIERS}

Beyond the operational deficiencies of the CDM, other institutional issues play a significant role in limiting the proliferation of CDM projects in Africa. Many of the problems plaguing development in Africa are not specific to the CDM, but rather are institutional challenges for all development sectors (Winkelman and Moore, 2011, p. 1132). Economic development on the African continent has been a vexing issue for decades. Weak and corrupt institutions, high population growth, declining external resource flows, growing external debt, inadequate social development, lack of infrastructure and environmental constraints, high rates of poverty, low standard of living and disease pandemics present countries in Africa with some of the most daunting challenges of any region on earth (Nelson, 2004, pp. 616-618).

Many of these problems have the potential to deteriorate further in the coming decades as Africa begins to feel the impact of global climate change: water and food shortages, mass migration, the creation of climate change 
refugees, resource wars, draught, flooding, desertification, and sea level rise (Nelson, 2004, pp. 616-618). Despite the African continent's minimal contribution to the global warming problem, scientists expect the effects of global climate change to affect Africa disproportionately (Sum Low, 2006, pp. 76-80). Current projections indicate that developing countries face 75 to 80 per cent of the potential damage from climate change. ${ }^{59}$

From an institutional perspective, the barriers to the successful implementation of CDM projects on the African continent are dividable into two categories: (1) climate change-related problems and (2) economic developmentrelated problems. In terms of economic development challenges, Africa is plagued with a high-risk environment (weak rule of law traditions, high levels of graft and corruption, and poor governance standards) that limits the amount of FDI flowing onto the continent (Nelson, 2004, p. 634). Since the funding of $\mathrm{CDM}$ projects comes primarily from private investment, such a limitation is important.

A further economic-related barrier stems from the mismatch between the climate-focused priorities of the CDM and the economic development-focused priorities of LDCs on the African continent. Climate change-related challenges include the lack of capacity and technical knowledge needed to adapt to climate change, the problems created by the limited involvement of Non-Annex I countries in the UNFCCC decision-making process, and the disconnect between GHG reduction priorities of the developed world and the energy development priorities of countries in Africa. ${ }^{60}$ The African continent, despite its abundance of natural resources, accounts for only 2.5 per cent of the world's economic activity (Nelson, 2004, p. 634). Some non-governmental organizations hold that it is Africa's very low levels of energy consumption (2-3 per cent of the world's energy consumption) that are both the cause and consequence of underdevelopment (Nelson, 2004, pp. 634-635). Bringing energy to African populations, sustainable or not, is an exceedingly difficult problem.

The African continent continues to have the lowest rate of FDI globally: an acknowledged necessity for financing energy projects in the poorest regions of the world (Udombana, 2002, p. 304). While global strategies to increase FDI and improve governance in less developed countries is beyond the scope of this chapter, there are modifications to the CDM that might be able to increase FDI flows in developing countries: investment incentives and protection mechanisms, vehicles for technology transfer, and information dissemination about emerging carbon trading markets. ${ }^{61}$

Another barrier to the promotion of CDM projects on the African Continent stems from a mismatch between the priorities of the CDM and the development priorities of countries in Africa. The CDM focuses on GHG emission reductions through two major categories of projects: (1) GHG capture of industrial and agricultural gases, and (2) the promotion of clean technologies 
that either clean up or replace dirtier fossil fuel based energy production systems (Ellis and Kamel, 2007, pp. 11-12). With few such opportunities in Africa, the majority of eligible CDM projects do not address the African continent's need for projects that both increase access to energy and adapt to future climate change problems (Byigero, 2010). Further, the primary development agenda for countries in Africa remains food, water, and energy security - as the majority population on the continent is still living in poverty (Nelson, 2004, p. 625).

While the MDGs do not deal specifically with energy development and climate change, the achievement of the MDGs in Africa will require both climate change adaption and increased access to sustainable energy (Subbarao and Lloyd, 2011, p. 1600). To date, Africa has experienced little industrial development compared to the rest of the world. As there is a perceived historical relation between fossil fuel consumption and prosperity, the African continent is still awaiting its industrial revolution. From the African perspective, access to energy, sustainable or not, is high on the development agenda (Nelson, 2004, p. 625). Without strong incentives to develop along a sustainable energy path, Africa's future industrialization could follow the same unsustainable fossil fuel model that is now challenging the developed world.

The CDM, primarily a GHG reduction mechanism, is ill equipped to incentivize the development of a sustainable energy system for an entire continent. Further, as environmental restrictions become more limiting in the developed world, an increase in the dumping of polluting technologies in Africa is likely to produce leakage. Therefore, policies to disincentivise the promotion of fossil fuel based energy systems on the African continent are important and can benefit both the developing and developed world in long-term global efforts to adapt to climate change.

Another institutional barrier preventing the utilization of the CDM on the African continent is the limited role that Non-Annex I countries play in the development of the global climate change regime. The UNFCCC continues to promote a posture of common, but differentiated responsibilities for members of the convention. ${ }^{62}$ While such an approach is crucial in setting GHG emission reduction commitments under the Kyoto Protocol, it has created considerable difficulties in developing a comprehensive global regime to address climate change.

Developed countries (primarily the US) have always criticized the Kyoto Protocol's refusal to set GHG emission reduction commitments for emerging or transitional countries such as India and China (Gerrard, 2007, p. 21). While the rejection of the Kyoto Protocol by the US is proving to be an unsophisticated and detrimental approach, the LDCs appear to support the US point of view; however, for completely different reasons. Under the current regime, countries with no commitments play a limited role in the decision-making 
process (Nelson, 2004, p. 636). Likewise, Non-Annex I countries are restricted in their participation in the market for trading carbon emission credits.

One possible approach to this problem is to allocate emission rights among all states on a per-capita basis (Nelson, 2004, p. 636). The per-capita approach reflects the view that all of the world's population has an equitable right to share equally in the use of the atmosphere. Under such an approach, developed countries currently overusing their share of the atmosphere's assimilative capacity will gradually reduce emissions while the underdeveloped regions of the world would increase their emissions until they reach a comparable state of economic development (Nelson, 2004, p. 636).

A final institutional hurdle to the promotion of CDM projects on the African continent is its extensive use of unsustainable biomass as a primary energy source. The population on the African continent is as diverse and complex as any region of the world; however, the majority of the population is rural, agrarian, and pre-industrial. As mentioned, energy infrastructure is almost nonexistent in rural areas on the continent. What infrastructure does exist is crumbling and unreliable (Nelson, 2004, pp. 625-626). The primary energy source for Africa's rural population is biomass - such as fuelwood and agricultural and animal residues (Bluemel, 2007, p. 675). While biomass energy provides about 11 per cent of the global primary energy supply, the share of biomass in primary energy consumption on the African continent is around 70 per cent (Bluemel, 2007, p. 675). Since the CDM is primarily concerned with reducing GHG emissions, it fails to address many of the land use issues that would be required to disincentivise the destruction of forests for fuelwood (Ellis and Kamel, 2007, pp. 11-12).

Considering that 70 per cent of the energy in Africa comes from unsustainable biomass consumption, any mechanism for promoting sustainable energy development in African needs to include provisions for promoting alternatives to such use (Lecocq and Ambrosi, 2007, pp. 147-148). One of the major problems of current patterns of unsustainable biomass use is its low conversion efficiency. Domestic use of fuelwood has a conversion rate of about 10 per cent (Bluemel, 2007, p. 675). Such inefficiency creates social development problems as children and women in rural areas on the African continent can spend up to seven hours a day collecting fuel for cooking. ${ }^{63}$ Further, smoke from the burning of biomass on open fires kills an estimated 2.5 million women and children annually, with such prolonged smoke inhalation being a major factor in the contraction of acute respiratory infection. ${ }^{64}$ Providing fuel switching to cleaner and more efficient energy sources could transform rural Africa. Not only would the development of simple renewable decentralized energy systems provide the rural poor with a greatly enhanced standard of living, it would also reduce the amount of fuelwood harvested from forests. However, under the current CDM, sustainable biomass projects have been few in number. ${ }^{65}$ 


\subsection{OVERCOMING OPERATIONAL AND INSTITUTIONAL BARRIERS}

In order for the CDM to become an effective tool for promoting energy development on the African continent, three post-Kyoto scenarios seem feasible. The first scenario keeps the basic CDM framework in future commitment periods, while reforming the current regime's shortcomings (Wara, 2008, p. 1765). A second approach is to abandon the market-based approach and adopt a fundbased approach best exemplified by the Montreal Protocol's Multilateral Fund. ${ }^{66} \mathrm{~A}$ fund-based approach has the potential to encounter problems similar to those currently challenging the CDM. However, it could increase the efficiency of the flexible mechanisms, increase the ability to target projects that create tangible sustainable development benefits, and increase the ability for implementing projects that are necessary (such as renewable energy projects on the African continent), but not economically feasible under a market-based system.

Despite the potential advantages of a fund-based program, it has been assumed that the post-Kyoto framework is likely to be market-based (Ellis and Kamel, 2007, pp. 40-41). Yet, recent developments in a fund-based approach have been significant. ${ }^{67}$ The World Bank Group's Clean Technology Fund and the Strategic Climate Fund, ${ }^{68}$ the proposed Green Climate fund currently being developed by the UNFCCC COP, ${ }^{69}$ the UN Adaptation Fund, ${ }^{70}$ and the various national climate funds that individual developed countries have established constitute a serious trend away from purely market-based solutions to climate change. Statements that the CDM will continue to function, coupled with the recent proliferation of climate funds, indicates that a hybrid approach is actually emerging. This third scenario appears more and more likely to represent the path that the global community takes in its efforts to curb climate change.

Regardless of what approach becomes dominant in the post-Kyoto era, the continued reform of the CDM in the short-term remains important. From the macro level, increasing FDI flows to Africa in the coming years is important (Ellis and Kamel, 2007, pp. 16-17). In Africa, access to project financing limits the potential of CDM projects specifically, and sustainable development projects generally. ${ }^{71}$ The future of any CDM-type program Africa will require increased levels of FDI, and developed countries can encourage these increases through various investment incentives and guarantees. More specifically, there are a number of CDM-based methods that could be pursued.

One approach could be to create a quota system that caps the number of projects in individual countries (Nelson, 2004, p. 635). By limiting the number of projects in faster developing countries (such as China, Brazil, and India), 
the CDM could compel investment in higher risk environments (such as LDCs) (Schatz, 2008, pp. 708-709). A quota system would likely limit the number of low-hanging fruit projects. This limitation on the number of lowcost projects would have the potential to compel investment in more expensive sustainable energy projects.

Another approach could be to include a mechanism allowing for a full menu of emission reduction strategies in slower developing countries but limit the strategies given to faster developing countries. Likewise, the CDM could be modified in a manner that sets the value of CER credits on a sliding scale: for example, a CDM project in a faster developing country might receive 0.5 times emission reductions, while LDCs receive full credit. Along these lines, the current CDM strategy to promote projects in LDCs includes the aforementioned policy to provide incentives, assistance, and loans to countries that have registered fewer than 10 projects. ${ }^{72}$

The future success of a CDM-type program on the African continent will also require the allowance of GHG avoidance projects, not just GHG reduction projects. Such an outlook will allow a variety of projects that create incentives to make better land use choices. This will require a new definition of sustainable development under the CDM; a definition that would encompass a full range of mitigation and adaptation projects that currently do not fit neatly into the clean development box: reforestation and afforestation projects, livestock projects, land use projects, hydropower projects, gas capture, and industrial gas reduction projects. Further, in order to promote long-term renewable energy projects and true carbon sink projects through the CDM, the international community must agree to binding future commitment periods in an effort to provide certainty in the long-term viability of a global carbon market.

The CDM to date has had considerable success in providing low-cost GHG reduction opportunities to developed world countries. However, critics of the CDM hold that even this aspect has been a failure. A 2007 study found that a major class of CDM projects (HFC-23 abatement projects) paid as much as 50 times more for its GHG emission reductions than the costs alone would warrant, with the excessive profits ending up with the factories and the carbon traders (Wara, 2007, p. 595). Such projects have severely undermined the promotion of the CDM as a legitimate tool for achieving sustainable development objectives. The success of any future CDM-type program will require improvement to the substantive requirements of sustainable development in order to mandate that the developed world help pay for projects that promote climate change adaptation, but also provide economic and social development benefits to local populations in the poorest regions of the world. 


\subsection{CONCLUSION}

As the global climate change regime ramps up in coming years, it is important that efforts to promote sustainable energy development on the African continent likewise increase in scope. Arguably, we all bear a moral and financial duty to prevent slow developing countries from the suffering caused by the historically inequitable distribution of the world's resources. If developed properly, the CDM still has the potential to bring much needed capital and technical expertise to Africa. ${ }^{73}$ By helping LDCs adapt to climate change, the global community has the opportunity to reduce poverty and reduce GHG emissions at the same time. Yet, there is certainly the possibility that, absent specific reforms to the CDM, a market-based approach to climate change will only continue to address the problems facing the African continent inadequately.

\section{NOTES}

1. Gaye, A. (2007), Human Development Report 2007/2008 - Fighting Climate Change: Human Solidarity in a Divided World, United Nations Development Programme, http://hdr.undp.org/en/reports/global/hdr2007-8/ (accessed 9 February 2012).

2. Fourth Assessment Report (2007), United Nations Inter-governmental Panel on Climate Change, http://www.ipcc.ch/pdf/assessment-report/ar4/syr/ar4_syr.pdf, p. 4 (accessed 9 February 2012).

3. The Millennium Development Goals in Africa: Progress and Challenges (2005), United Nations Economic Commission for Africa, http://www.uneca.org/mdgs/MDGs_in_Africa. pdf, p.8 (accessed 9 February 2012).

4. The Millennium Development Goals Report 2010 (2010), United Nations Department of Economic \& Social Affairs, http://www.un.org/en/mdg/summit2010/pdf/MDG\%20Report\% 202010\%20En\%20r15\%20-low\%20res\%2020100615\%20-.pdf (accessed 9 February 2012).

5. The Kyoto Protocol to the United Nations Framework Convention on Climate Change (1997), 37 I.L.M. 22, http://unfccc.int/resource/docs/convkp/kpeng.pdf, 11 December (accessed 9 February 2012).

6. The eight Millennium Development Goals: (1) Eradicate extreme poverty and hunger, (2) Achieve universal primary education, (3) Promote gender equality and empower women, (4) Reduce child mortality, (5) Improve maternal health, (6) Combat HIV/AIDS, malaria, and other diseases, (7) Ensure environmental sustainability, and (8) Develop a global partnership for development.

7. Practical Action (2009), Energy Poverty: The Hidden Crisis, http://practicalaction.org/docs/ advocacy/energy_poverty_hidden_crisis.pdf, p. 3 (accessed 9 February 2012).

8. Murray, J. (2010), Cancun Green Fund to Dominate Global Climate Finance, Business Green, http://www.businessgreen.com/bg/news/1931989/cancun-green-fund-dominateglobal-climate-finance 13 December (accessed 9 February 2012).

9. Bird, N., et al. (2011), Design Challenges for the Green Climate Fund: Briefing Paper Climate Finance Policy Briefs, Overseas Development Institute, http://www.odi.org.uk/ resources/download/5256.pdf (accessed 9 February 2012).

10. Gillenwater, M. and S. Seres (2011), The Clean Development Mechanism: A Review of the First International Offset Program, Pew Center for Global Climate Change, http://www.pewclimate.org/docUploads/clean-development-mechanism-review-of-firstinternational-offset-program.pdf, p. 2 (accessed 9 February 2012). 
11. Above, n. 2, p. 4.

12. Ibid.

13. The United Nations Conference on Environment and Development: Framework Convention on Climate Change (1992), S. Treaty Doc. No. 102-38, 31 I.L.M. 849, http://unfccc.int/resource/docs/convkp/conveng.pdf, 9 May (accessed 9 February 2012). Annex I countries (industrialized countries): Australia, Austria, Belarus, Belgium, Bulgaria, Canada, Croatia, Czech Republic, Denmark, Estonia, Finland, France, Germany, Greece, Hungary, Iceland, Ireland, Italy, Japan, Latvia, Liechtenstein, Lithuania, Luxembourg, Monaco, Netherlands, New Zealand, Norway, Poland, Portugal, Romania, the Russian Federation, Slovakia, Slovenia, Spain, Sweden, Switzerland, Turkey, Ukraine, the United Kingdom, and the United States of America.

14. Fenhann, J. and M. Hinostroza (2011), CDM Information and Guidebook: Third Edition, United Nations Environment Programme CD4CDM Project, UNEP Ris $\varnothing$ Centre on Energy, Climate, \& Sustainable Development, http://cd4cdm.org/Publications/cdm_guideline_3rd_ edition.pdf, pp. 64-68 (accessed 9 February 2012).

15. Ibid.

16. All six major GHGs can earn CER credits; each credit represents the equivalent of one ton of $\mathrm{CO}_{2}$ emitted.

17. Although it can be noted that the emergence of the recent Green Climate Fund indicates that the adaptation fund approach has merit, albeit almost 20 years after it was initially proposed by the developing world.

18. Kamel, S. (2007), Guidebook to Financing CDM Projects, United Nations Environment Programme, CD4CDM Project, UNEP Ris $\emptyset$ Centre on Energy, Climate, \& Sustainable Development, http://cd4cdm.org/Publications/FinanceCDMprojectsGuidebook.pdf, p. 20 (accessed 9 February 2012).

19. Gunther, M. (2008), Carbon Finance Comes of Age, CNN Money, http://money.cnn.com/ 2008/04/15/technology/Gunther_carbon_finance.fortune/index.htm, 17 April, p. 1 (accessed 9 February 2012).

20. Venema, H. and M. Cisse (2004), Seeing the Light: Adapting to Climate Change with Decentralized Energy in Developing Countries, International Institute for Sustainable Development, http://www.iisd.org/cckn/pdf/seeing_the_light_dre.pdf, pp. 11-14 (accessed 9 February 2012).

21. The Marrakesh Accords (2001), Report of the Conference of the Parties on its Seventh Session, http://unfccc.int/cop7/documents/accords_draft.pdf, 10 November (accessed 9February 2012).

22. Above, n. 10, p. 29.

23. Each project must establish a clear baseline of anthropomorphic GHG emissions that would occur under a business as usual scenario.

24. Voluntary emission reductions are those not already compelled by national or provincial laws or regulations.

25. Real emissions are those monitored with sufficient care as to insure that they actually occur (in order to prevent false credits).

26. Additional emissions (the requirement of additionality) are ones that are in addition to any that would have occurred absent the CDM subsidy.

27. Leakage of emissions occurs when emission reductions that would have occurred absent the CDM subsidy move to another location because of the subsidy.

28. Wilder, M., et al. (2004), Legal Issues Guidebook to the Clean Development Mechanism, United Nations Environment Programme, CD4CDM Project, UNEP Risø Centre on Energy, Climate, \& Sustainable Development, http://cd4cdm.org/Publications/CDM\%20Legal\% 20Issues\%20Guidebook.pdf, p. 50 (accessed 9 February 2012).

29. LDCs with weak governance and under-developed institutions have had difficulty establishing DNAs. This problem has been a particular challenge for countries on the African continent.

30. DOEs, which are paid for by the project proponent, have conflict of interest issues relating to its potential to aid and abet in the strategic manipulation of baselines - which could lead to issuance of false credits. 
31. Wilder, M., et al. (2006), The Clean Development Mechanism: Special Considerations for Renewable Energy Projects, Yale-REIL-REEEP Roundtable on Renewable Energy \& International Law, Yale University Center for Environmental Law \& Policy, http://www.reilproject.org/Publications/REIL_CDM_Paper.pdf, p. 8 (accessed 9 February 2012).

32. For a prospectus on the current CDM reform agenda, see The CDM Annual Report (2010), Report to the Conference of the Parties Serving as the Meeting of the Parties to the Kyoto Protocol, Sixth Session, Cancun, Mexico, http://unfccc.int/resource/docs/2010/cmp6/eng/ 10.pdf, 29 November (accessed 9 February 2012).

33. Ibid, p. 49.

34. See, UNEP Ris $\emptyset$ CDM/JI Pipeline Analysis and Database - May 2011 Update: http://cdmpipeline.org/ (accessed 9 February 2012).

35. Ibid.

36. The renewable-type projects currently registered include biomass power, landfill gas capture, hydropower, reforestation/afforestation, fossil-fuel switch programs, geothermal power, wind power, and solar power.

37. See, UNEP Ris $\emptyset$ CDM/JI Pipeline Analysis and Database - May 2011 Update: http://cdmpipeline.org/ (accessed 9 February 2012).

38. Godoy, J. (2009), Wanted - A Truly Clean Development Mechanism, InterPress Service, http://www.ipsnews.net/news.asp?idnews=46699, 2 May (accessed 9 February 2012); Indians Make Cool $£ 300$ Million in Carbon Farce (2007), The Sunday Times, http://www.timesonline.co.uk/tol/news/uk/article1687531.ece, 22 April (accessed 9 February 2012).

39. Above, n. 10, pp. 29-31.

40. For an analysis of current CDM projects by type, see UNEP Ris $\emptyset$ CDM/JI Pipeline Analysis and Database - May 2011 Update: http://cdmpipeline.org/ (accessed 9 February 2012).

41. The CDM Annual Report (2010), Report to the Conference of the Parties Serving as the Meeting of the Parties to the Kyoto Protocol, Sixth Session, Cancun, Mexico, http://unfccc.int/resource/docs/2010/cmp6/eng/10.pdf, 29 November (accessed 9 February 2012).

42. Above, n. 10, pp. 30-31.

43. Olhoff, A., et al. (2007), CDM Sustainable Development Impacts, United Nations Environment Programme, CD4CDM Project, UNEP Ris $\varnothing$ Centre on Energy, Climate, \& Sustainable Development, http://cd4cdm.org/Publications/CDM\%20Sustainable\% 20Development\%20Impacts.pdf, pp. 6-10 (accessed 9 February 2012).

44. van Steenberghe, V., et al. (2005), Should Developing Countries Participate in the Clean Development Mechanism Under the Kyoto Protocol? The Low-Hanging Fruits and Baseline Issues, CORE Discussion Paper No. 2005/23, http://ssrn.com/abstract=880384, p. 15 (accessed 9 February 2012).

45. Above, n. 10.

46. The most commonly accepted definition originates from the Brudtland Commission: 'sustainable development is development that meets the needs of the present without compromising the ability of future generations to meet their own needs'.

47. New CDM Afforestation/Reforestation Projects Approved (2009), Green Collar, http://greencollarclimate.com.au/news/new-cdm-afforestationreforestation-projects-approved/, 5 April (accessed 9 February 2012).

48. Only $1 \%$ of current CDM projects are for LULUCF (land use, land use change, and forestry) project types (as of 15 May, 2011). There are currently a number of LULUCF-related challenges: projects are limited to reforestation and afforestation projects, projects only produce temporary CER credits since carbon sequestered in forests can be re-emitted, and CER credits earned from LULUCF projects are redeemable for only one percent of an Annex I countries emission reductions.

49. The Nairobi Framework: Capacity for Carbon Market Development in Sub-Saharan Africa - An Inter-Agency Program Proposal (2006), Report of the Conference of the Parties on its Thirteenth Session, http://cdm.unfccc.int/Nairobi_Framework/NF_partner_agencies.pdf, 17 November (accessed 9 February 2012).

50. Africa Carbon Forum website: http://africacarbonforum.com/2011/english/index.htm (accessed 9 February 2012). 
51. Above, n. 14, pp. 40-46.

52. Hinostroza, M, et al. (2009), A Primer on CDM Programme of Activities, United Nations Environment Programme CD4CDM Project, UNEP Ris $\varnothing$ Centre on Energy, Climate, \& Sustainable Development, http://cd4cdm.org/Publications/PrimerCMDPoA.pdf (accessed 9 February 2012).

53. Ibid, p. 13.

54. Examples of CDM Program of Activity (PoA) projects include programs for increasing energy efficiency in homes, domestic biogas programs, or small-scale fuel switching programs that provide cook stoves in regions currently using unsustainable biomass (fuelwood) as a primary energy source for cooking. As of May 15, 2011, 86 PoA projects have been registered. See, UNEP Ris $\varnothing$ CDM/JI Pipeline Analysis and Database - May 2011 Update: http://cdmpipeline.org/ (accessed 9 February 2012).

55. The Bali Action Plan (2007), Report of the Conference of the Parties on its Thirteenth Session, http://maindb.unfccc.int/library/view_pdf.pl?url=http://unfccc.int/ resource/docs/ 2007/cop13/eng/06a01.pdf, 15 December (accessed 9 February 2012).

56. The Copenhagen Accords (2009), Report of the Conference of the Parties on its Fifteenth Session, Draft Decision -/CP.15, http://unfccc.int/resource/docs/2009/cop15/eng/107.pdf, 18 December (accessed 9 February 2012).

57. The Cancun Adaptation Framework (2011), Report of the Conference of the Parties on its Sixteenth Session, http://unfccc.int/resource/docs/2010/cop16/eng/07a01.pdf\#page=4, 15 March (accessed 9 February 2012).

58. CDM Post-2012 Frequently Asked Questions (2010), Climate Connect, http://www.climateconnect.co.uk/Home/sites/default/files/Post\%202012\%20FAQs\%20CDM.pdf (accessed 9 February 2012).

59. World Development Report 2010: Development and Climate Change, The World Bank Group, http://siteresources.worldbank.org/INTWDR2010/Resources/5287678-122601452 7953/WDR10-Full-Text.pdf (accessed 9 February 2012, p. 5.

60. This is particularly a problem regarding the CDM's limited capacity to deal with Africa's use of unsustainable biomass (fuelwood, charcoal, and agricultural, and livestock residues) as a primary energy source.

61. Seres, S. (2009), Analysis of Technology Transfer in CDM Projects, United Nations Framework Convention on Climate Change, http://cdm.unfccc.int/Reference/Reports/ TTreport/index.html (accessed 9 February 2012).

62. Above, n. 5 .

63. Sustainable Energy for Poverty Reduction: An Action Plan (2002), Intermediate Technology Development Group, http://www.itdgpublishing.org.uk/docs/advocacy/itdg-greenpeacestudy.pdf (accessed 9 February 2012).

64. Ibid.

65. See, UNEP Ris $\varnothing$ CDM/JI Pipeline Analysis and Database - May 2011 Update: http://cdmpipeline.org/ (accessed 9 February 2012).

66. The Multilateral Fund for the Implementation of the Montreal Protocol (2007), Secretariat of the Multilateral Fund for the Implementation of the Montreal Protocol, http://www.multilateralfund.org (accessed 9 February 2012).

67. At both the 2009 UNFCCC COP in Copenhagen, Denmark and the 2010 UNFCCC COP in Cancun, Mexico, the development of a robust Green Climate Fund has been progressing. The Copenhagen Accord that was signed at the Copenhagen summit calls for the development of a Green Climate Fund that will facilitate the financing of adaptation and mitigation in the developing world. The 2010 Cancun summit focused on making the Green Climate Fund operational and the success of the 2011 UNFCCC COP in Durban, South Africa will likely be measured in terms of the Fund becoming a reality. The Fund aspires to secure 100 billion US dollars a year by 2020, but the details remain largely undeveloped as of mid-2011.

68. World Bank Group Climate Investment Funds website: http://www.climateinvestmentfunds.org/cif/ (accessed 9 February 2012).

69. Above, n. 57.

70. United Nations Adaptation Fund website: http://www.adaptation-fund.org/ (accessed 9 February 2012). 
71. Dupasquier C. and P. Osakwe (2005), Foreign Direct Investment in Africa: Performance, Challenges, and Responsibilities, United Nations Economic Commission for Africa, Africa Trade Policy Centre, Working Paper No. 21, http://www.uneca.org/atpc/Work\% 20in\%20progress/21.pdf (accessed 9 February 2012).

72. Above, n. 41.

73. Dechezleprêtre, A., et al. (2007), The Clean Development Mechanism and the International Diffusion of Technologies: An Empirical Study, Fondazione Eni Enrico Mattei, Note di Lavoro Series, http://hal.inria.fr/docs/00/39/71/98/PDF/10509.pdf (accessed 15 February 2012).

\section{REFERENCES}

Bluemel, E. (2007), 'Biomass Energy: Ensuring Sustainability through Conditioned Economic Incentives', Georgetown International Law Review, 19, 673.

Byigero, A., et al. (2010), 'CDM in Sub-Saharan Africa and the Prospects of the Nairobi Framework Initiative', Climate Policy, 10, 181.

de Lopez, T., et al. (2009), 'Clean Development Mechanism and Least Developed Countries: Changing the Rules for Greater Participation', Journal of Environment \& Development, 18, 436.

Ellis, J. and S. Kamel (2007), Overcoming Barriers to Clean Development Projects, Organization for Economic Cooperation \& Development Report, COM/ENV/EPOC/IEA/SLT(2007)3.

Fenhann, J. and F. Staun (2010), 'An Analysis of Key Issues in the Clean Development Mechanism Based on the UNEP Ris $\varnothing$ Clean Development Mechanism Pipeline', Carbon Management, 1, 65.

Gerrard, M. (2007), Global Climate Change and U.S. Law, New York, American Bar Association, Section of Environment, Energy, \& Resources.

Laurance, W. (2007), 'A New Initiative to Use Carbon Trading for Tropical Forest Conservation', Biotropica, 39.

Lecocq, F. and P. Ambrosi (2007), 'The Clean Development Mechanism: History, Status, and Prospects', Review of Environmental Economics \& Policy, 1, 134.

Nelson, P. (2004), 'An African Dimension to the Clean Development Mechanism: Finding a Path to Sustainable Development in the Energy Sector', Denver Journal of International Law \& Policy, 32, 615.

Nygard, J., et al. (2009), Clean Development Mechanism in China: Ensuring a Sustainable Approach, Washington D.C.: World Bank Publications.

Schatz, A. (2008), 'Discounting the Clean Development Mechanism', Georgetown International Environmental Review, 20, 703.

Subbarao, S. and B. Lloyd (2011), 'Can the Clean Development Mechanism (CDM) Deliver?' Energy Policy, 39. 1600.

Sum Low, P. (ed.) (2006), Climate Change and Africa, Cambridge: Cambridge University Press.

Timilsina, R., et al. (2010), 'Clean Development Mechanism Potential and Challenges in Sub-Saharan Africa', Mitigation \& Adaption Strategies for Global Change, 15, 93.

Udombana, N. (2002), 'How Should We Then Live? Globalization and Africa's Development', Boston University International Law Journal, 20, 302.

Wara, M. (2007), 'Is the Global Carbon Market Working?' Nature, 445, 595.

Wara, M. (2008), 'Measuring the Clean Development Mechanism's Performance and Potential', UCLA Law Review, 55, 1759. 
Winkelman, A. and M. Moore (2011), 'Explaining the Differential Distribution of Clean Development Mechanism Projects Across Host Countries', Energy Policy, 39, 1132.

Wright, D. (2007), The Clean Development Mechanism, Saarbrücken, Germany: VDM Verlag Dr. Mueller e.K.

Yasmin, F. (1998), 'The Kyoto Protocol: Origins, Assesment, and Future Changes', Reveiw of European Community and International Environmental Law, 7, 113. 